\title{
An accurate prediction of maize crosses using diallel analysis and best linear unbiased predictor (BLUP)
}

\author{
Gustavo H.F. Oliveira ${ }^{1 *}$, Rodolfo Buzinaro ${ }^{1}$, Lucas T.M. Revolti ${ }^{1}$, \\ Carlos H.B. Giorgenon ${ }^{2}$, Kauê Charnai ${ }^{3}$, Diego Resende ${ }^{4}$, and Gustavo V. Moro ${ }^{1}$
}

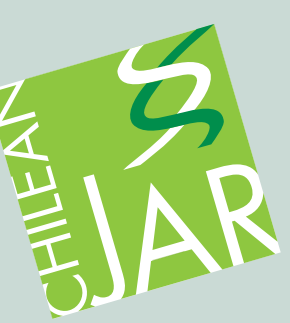

\section{ABSTRACT}

A major obstacle in corn (Zea mays L.) breeding programs is how to obtain strains which, when combined, ensure increased productivity in all crop characteristics. Therefore, the objective of this study was to evaluate the prediction efficiency of hybrid maize using diallel analysis and the best linear unbiased predictor (BLUP). Eight synthetic varieties were sown in a diallel scheme and the hybrid and their parents were then evaluated in three separate environments; both combining ability and predicted breeding values (BLUPs) were estimated. Correlations between the BLUP and combining abilities were also obtained. Combining ability analysis revealed that both additive and non-additive types of gene action were important in the studied traits. There was a moderate to high correlation between the mean square of the combining ability and the predicted breeding values. This shows that BLUP can be used to select the best parents for different traits, especially for ear height and ear position, which had the highest correlations. The parent VAR-01 had significant general combining ability (GCA) values, and it can be used in crosses to reduce plant height, ear height, and ear position while the parent VAR-06 can participate in crosses to increase ear height, plant height, and ear position. The result obtained for combining ability was moderately to highly consistent with BLUP results, but selection must be carefully undertaken.

Key words: GCA, mixed models, SCA, Zea mays.

${ }^{1}$ Universidade Estadual Paulista 'Julio de Mesquita Filho', Faculdade de Ciências Agrárias e Veterinárias, via de acesso Prof. Paulo Donato Castellane s/n 14884-900, Jaboticabal, São Paulo, Brasil. "Corresponding author (gustavo.genetica@ posgrad.fcav.unesp.br). ${ }^{2}$ DuPont do Brasil-Pioneer Sementes, Centro de Pesquisa de Palmas Rural 77500000, Palmas, Tocantins, Brasil.

${ }^{3} \mathrm{GDM}$ Genética do Brasil, rua $16 \mathrm{~N}^{\circ} 808$, parque Bandeirantes, Rio Verde, Goias, Brasil.

${ }^{4}$ PROCOOP, Rua Revalino Pereira, No 325, 38400344, Uberlândia, Minas Gerais, Brasil.

Received: 18 February 2016.

Accepted: 29 June 2016

doi:10.4067/S0718-58392016000300005

\section{INTRODUCTION}

A major difficulty in corn (Zea mays L.) breeding programs is finding strains which, when combined, ensure high gains in all crop characteristics, as well as reduced ability to evaluate large numbers of field crosses (Guo et al., 2013). Furthermore, the availability of variability is critical to successful selection.

There are several methodologies for selecting lines with high favorable allele frequency, for example, reciprocal recurrent selection (Faria et al., 2009). These methods require evaluating lines in multiple cycles of hybrid combinations, which is a slow and costly process. The diallel cross method is used to facilitate genotype selection, especially because of the crossing combining ability of these genotypes. In these crosses, a mathematical model is used to select parents and determine heterotic groups (Griffing, 1956). Even though genetic factors can be considered random, they are usually included in the fixed-effects coincidence matrix; this therefore excludes the use of mixed models, which allow, for example, unbalanced data analysis (Henderson, 1975).

The mixed model methodology has some advantages, such as predicting unrealized crosses (Cruz Baldissera et al., 2012; Gowda et al., 2013a), obtaining unbiased linear predictions, the best linear unbiased prediction (BLUP) for the random effects (genetic), and the best linear unbiased estimate (BLUE) for the fixed effects, associated with the estimated variance components for restricted maximum likelihood (REML). The use of this tool in breeding programs reduces time and costs by directly testing only the most promising crosses.

Using BLUP as a selection tool and predictor of unknown crosses is very effective (Gowda et al., 2013b). Efficient strain selection of unknown crosses depends on knowing the degree of the parents' relationship (Bernardo, 1995).

Thus, the aim of this study was to evaluate and predict the accuracy of maize crosses using diallel analysis and best linear unbiased predictor (BLUP).

\section{MATERIALS AND METHODS}

The procedure to obtain the varieties and intervarietal hybrids consisted in separating 158 inbred maize genotypes from different origins into eight groups according to origin and time to maturity. These genotypes were sown to achieve the "sib" (self in brothers) chain intersection scheme. All possible crossing combinations were made among the same genotype group. After harvesting, each group's seeds were sown in eight isolated plots for recombination. 
Isolation was performed with a minimum distance of $300 \mathrm{~m}$ from any maize crop and/or 30-d temporal isolation when necessary. At harvest, the ears of all plants in each plot were collected and seeds were mixed, resulting in the eight varieties for this study.

Subsequently, the eight synthetic varieties were seeded in a diallel cross scheme where each array had been artificially crossed with all other possible combinations, except reciprocal combinations. A total of 28 intervarietal hybrids were evaluated along with the parental strains in three different environments. The experiment was conducted in the 20092010 crop year in three environments. The first crop (first environment) and second crop (second environment) were grown at the experimental farm at the Universidade Estadual Paulista 'Julio de Mesquita Filho' (UNESP), Jaboticabal (21 ${ }^{\circ} 15^{\prime} 17^{\prime}$ ' S, 48 19 '20” W; 605 m a.s.1.) in São Paulo, Brazil, and a second crop (third environment) was grown in Campo Alegre de Goiás (17³7'59" S, 4746’42” W; 877 m a.s.1.) in Goiás, Brazil. The climate in both locations is considered as tropical Aw (Koppen classification) with average rainfall of $60 \mathrm{~mm}$ in the driest month and average temperature of 18 ${ }^{\circ} \mathrm{C}$ in the coldest month of the year. The average temperature is $29{ }^{\circ} \mathrm{C}$ in the rainy seasons. Soil typesin both locations are classified as Eutrophic Red Latosol and Dystrophic Red Latosol, respectively (Embrapa, 2006).

The experiment was conducted with a randomized block design and three replicates. The plots consisted of four 5-m long rows with a spacing of $20 \mathrm{~cm}$ between plants and $90 \mathrm{~cm}$ between rows; this resulted in a population of 55555 plants per hectare. Only the two central rows of each plot were used for seed collection. The crops were JAB09/10 (first crop, Jaboticabal 2009-2010), SJAB10 (second crop, Jaboticabal 2010), and SGO10 (second crop, Goiás 2010).

To evaluate varieties and intervarietal hybrids, the studied variables were ear height $(\mathrm{EH}, \mathrm{cm})$, plant height $(\mathrm{PH}, \mathrm{cm})$, ear position (EP), EH:PH ratio t, and grain yield $\left(\mathrm{GY}, \mathrm{kg} \mathrm{ha}^{-1}\right)$. Plot production data were corrected to $13 \%$ moisture and adjusted based on the covariance method and converted into $\mathrm{kg} \mathrm{ha}^{-1}$ (Silva et al., 2014).

Data were subjected to statistical analysis. A homogeneity test of the data was applied according to Bartlett's test (Bartlett, 1937) and a combined ANOVA was then performed on the three environments.

The diallel analyses were performed with the Diallel-05 package of the SAS program (Zhang et al., 2005), which takes into account the Griffing (1956) diallel model II (random effect), method 2, and analyzes the crosses and parents without reciprocal crosses. The general combining ability (GCA) and specific combining ability (SCA) were estimated. The model proposed by Griffing (1956) analyzes the diallel table by decomposing the average $v_{i j}$ in the following equation:

$$
v_{i j}={ }_{X}+g_{i}+g_{j}+s_{i j}+\frac{1}{b} \sum_{k} b_{k}+\frac{1}{b} \sum_{k}(b v)_{i j k}+\frac{1}{b c} \sum_{k} \sum_{l} e_{i j k l}
$$

where $v_{i j}$ is the average phenotypic value observed in the plot for the $\mathrm{i}^{\text {th }}$ and $\mathrm{j}^{\text {th }}$ genotypes; $\mu_{X}$ is the average general effect; $g_{i}+g_{j}$ is the effect of GCA associated with the $i^{t h}$ and $j^{\text {th }}$ parents, respectively; $s_{i j}$ is the effect of SCA as $s_{i j}=s_{j i} ; k$ is the number of varying plots $1, \ldots, \mathrm{b} ; b v$ is the effect of the block $\times$ genotype interaction; $c=p^{2}-p+1$ when $p$ is the number of progenitors; and $e_{i j k l}$ is the average random error associated with the observations $i j k l$.

In this model, it is assumed that both $\sum_{i} g_{i}=0$ and $\sum_{i \neq j} s_{i j}=0$ (for each $j$ ) are imposed on the effects of combining ability. The relative additive effects involved in determining the characteristics assumed the absence of epistasis and calculated GCA and SCA in each studied characteristic by the ratio of the mean squares:

$$
\% \mathrm{GGA}=\frac{G C A}{G C A+S C A} \times 100
$$

We also estimated BLUP for parents and their crosses with the experimental data. The BLUP, GCA, and SCA estimates of the genotypes were correlated. The BLUP and correlation coefficients were provided by the PROC MIXED and PROC COR function, respectively, of SAS 9.3 (SAS Institute, Cary, North Carolina, USA).

\section{RESULTS AND DISCUSSION}

There were significant differences $(\mathrm{P}<0.01)$ among genotypes for all analyzed variables (Table 1) and there was variability among tested materials. This is of paramount importance for obtaining genetic gains in terms of hybrid crosses among populations since the success of the breeding program depends on variability to optimize the selection process (Machado, 2014). For all analyzed variables, the variation coefficients were at or below the ideal described by Hallauer et al. (2010) and Fritsche-Neto et al. (2012) and revealed high experimental precision.

The sum of squares for treatments was arranged in GCA and SCA. Significant GCA effects were observed for PH, $\mathrm{EH}$, and $\mathrm{EP}$, thus revealing significant differences between parents, or at least the existence of a superior parent, among all those evaluated related to their mean performance in hybrid combinations. The presence of a significant GCA indicates the importance of additive genetic effects on the expression of the evaluated characteristic. For a set of parents, this directly involves the artificial selection of plants with desirable characteristics that also produce progeny with increased or favorable performance (Rocha et al., 2014). However, for GY, a high frequency of non-additive effects of alleles was found because only $27.80 \%$ was due to additive effects (Table 1).

In the diallel analysis, additive effects explained more than $65 \%$ of the variation, except for GY (Table 1). This superiority of GCA over SCA is also observed in other maize studies (Vivek et al., 2010; Rocha et al., 2014). Even with a high and significant effect of GCA, one cannot ignore dominance effects. Rangel et al. (2007) obtained predominantly non-additive effects for $\mathrm{PH}$, which is different from what we observed in the present study. Furthermore, as seen in a simple top-crossing using only one tester, combining ability is calculated as the difference between the top-crossed hybrid and population mean; 
Table 1. Summary of ANOVA for general combining ability (GCA) and specific combining ability (SCA).

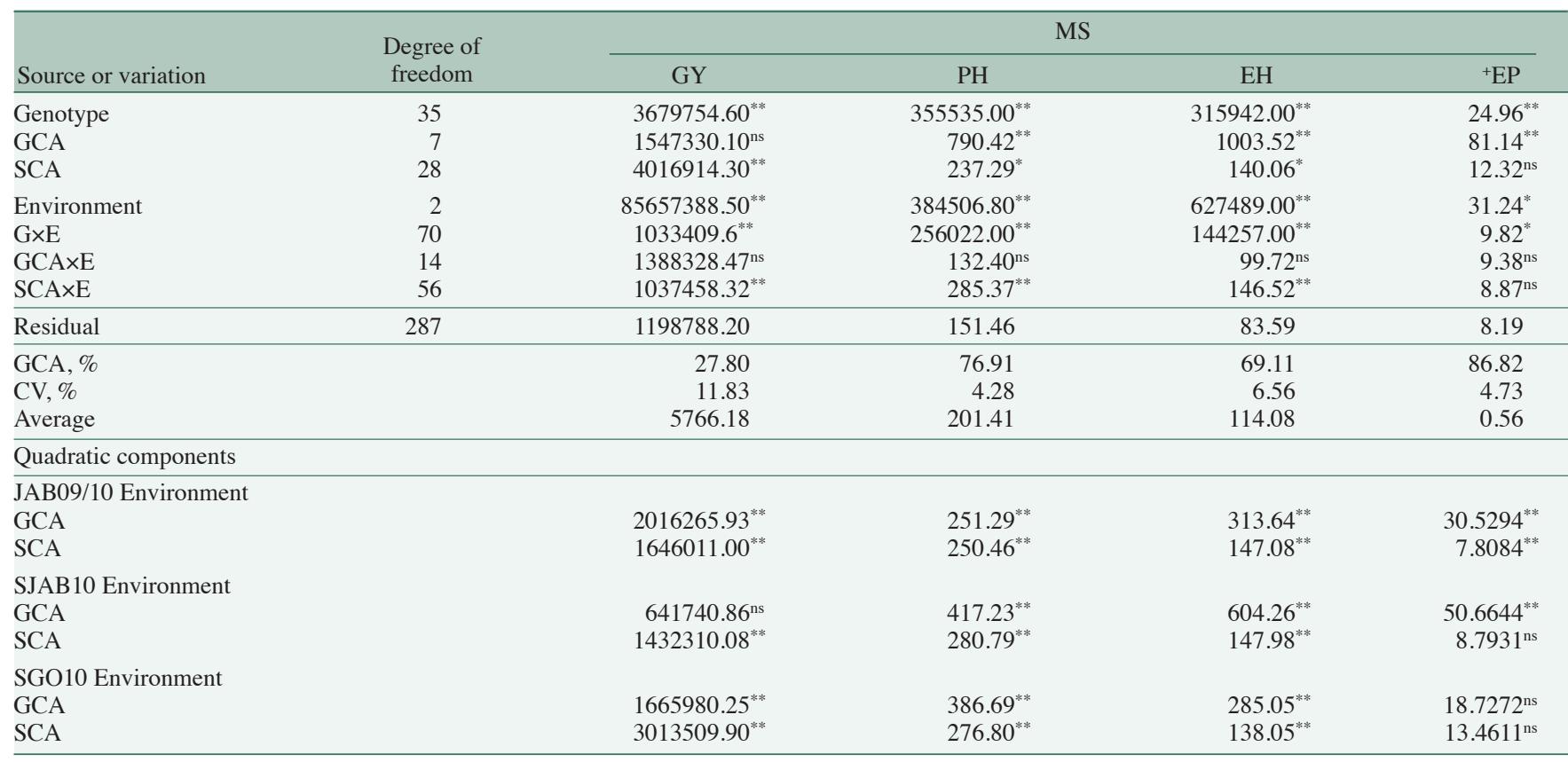

* ${ }^{* *}$ Significant at the 0.05 and 0.01 probability levels, respectively,

${ }^{\mathrm{n}}$ nonsignificant.

MS: Mean square; GY: grain yield variables $\left(\mathrm{kg} \mathrm{ha}^{-1}\right)$; PH: plant height (cm); EH: ear height (cm); EP: ear position.

+Value multiplied by 10000 .

both the deviation of the heterozygote related to the mean and frequency of favorable alleles on the tester directly participate in estimating GCA. Since it has been proven that the locus influences the effect of GCA dominance, we can say that the predominance of GCA for the variable under study does not necessarily imply a lack of dominance. This would be possible only if the loci involved in the character's expression had a frequency of 0.5 (Ribeiro et al., 2014).

The SCA showed a significant effect on all the variables, except for EP which indicated different complementarity between parents, thus enabling the production of high-yielding hybrids. The significance of SCA for productivity reflects a high divergence of the involved parents and indicates that these parents have a higher number of heterozygous loci; the formed population will therefore have a greater range of variation and be favorable for selection (Vencovsky, 1972). Breeding programs generally want hybrid combinations with high SCA estimates that involve at least one parent with high GCA (Cruz Baldissera et al., 2012).

Significant Genotype $\times$ Environment interactions $(\mathrm{G} \times \mathrm{E})$ were observed for all traits. When this type of interaction exists, it presupposes that there is a variation between the same genotypes in different environments and is directed toward a particular selection. In this case, it probably resulted from the significant effect of SCA $\times \mathrm{E}$; assuming that the hybrids showed greater differences than the parents in the evaluated environments, an individual GCA and SCA analysis is therefore required for each environment (Werle et al., 2014).

There was no difference in the mean performance between parents according to environmental variations revealed by the nonsignificance of the GCA $\times \mathrm{E}$ source of variation. This type of interaction for parents is very important for using diallel components in breeding programs (Júnior et al., 2006). According to the quadratic components, there was a slight difference in performance (yield) between parents only in the SJAB10 environment (Table 1). The individual analysis for parents' combining ability showed high and significant GCA, except for the SJAB10 environment. This means that parents can be used for intra-population breeding programs aimed at establishing generations with higher productivity gains.

Contrasts show that there was variability between parents (Table 2). The existence of variability between parents participating in crossings shows the importance of obtaining genetic variability and subsequent selection of promising genotypes in segregating generations (Cruz Baldissera et al., 2012). Selection should be performed so that values can be reproduced in the assessment of subsequent generations, especially for long-term breeding programs aimed at maximizing the distance between parents to explore heterosis.

Attaining genetic gains for every characteristic is always the target of breeding programs when the goal is to release cultivars. These characteristics are usually PH, EH, and GY among others. For example, Ribeiro et al. (2014) found that selecting for tassel size significantly affects grain production due to nutrient targeting. Oliboni et al. (2013), who used diallel analysis, obtained parents with the potential to segregate populations for inter-population improvement because of the increased ability for EH and husked ear productivity. Aguiar et al. (2004) selected promising maize lines for GY, PH, and EH by complete diallel analysis in four environments. Machado et al. (2009) obtained lines with 
Table 2. Mean between eight maize varieties and their crosses.

\begin{tabular}{lcrrc}
\hline & \multicolumn{4}{c}{ Mean phenotype } \\
\cline { 2 - 5 } Parent & GY & PH & EH & EP \\
\hline VAR-01 & 5554.75 & 198.15 & 107.73 & 0.54 \\
VAR-02 & 5367.64 & 196.48 & 111.16 & 0.57 \\
VAR-03 & 5391.28 & 199.91 & 115.09 & 0.57 \\
VAR-04 & 5502.69 & 203.98 & 114.58 & 0.55 \\
VAR-05 & 4681.00 & 202.36 & 117.73 & 0.58 \\
VAR-06 & 4634.01 & 214.54 & 123.28 & 0.57 \\
VAR-07 & 3888.92 & 209.31 & 123.25 & 0.59 \\
VAR-08 & 4522.25 & 214.72 & 123.52 & 0.57 \\
General mean & 4942.82 & 204.93 & 117.04 & 0.57 \\
Contrast & 1665.83 & 18.24 & 15.79 & 0.05 \\
Hybrids & & & & \\
C1X2 & 5923.86 & 187.59 & 98.22 & 0.52 \\
C1X3 & 6040.67 & 194.07 & 107.96 & 0.55 \\
C1X4 & 5594.37 & 192.59 & 103.61 & 0.54 \\
C1X5 & 5861.12 & 199.63 & 108.24 & 0.54 \\
C1X6 & 6439.54 & 190.37 & 108.06 & 0.57 \\
C1X7 & 5954.81 & 196.11 & 112.59 & 0.57 \\
C1X8 & 6042.47 & 197.04 & 106.02 & 0.54 \\
C2X3 & 6301.00 & 199.72 & 111.11 & 0.56 \\
C2X4 & 6061.16 & 201.39 & 111.48 & 0.55 \\
C2X5 & 5756.54 & 202.59 & 115.00 & 0.57 \\
C2X6 & 6462.13 & 210.37 & 119.81 & 0.56 \\
C2X7 & 5746.83 & 203.61 & 109.91 & 0.54 \\
C2X8 & 7152.05 & 209.63 & 117.50 & 0.56 \\
C3X4 & 5903.12 & 193.89 & 111.02 & 0.57 \\
C3X5 & 5679.18 & 196.39 & 111.85 & 0.57 \\
C3X6 & 6596.02 & 205.46 & 119.54 & 0.58 \\
C3X7 & 5888.68 & 202.78 & 118.43 & 0.58 \\
C3X8 & 5226.01 & 198.43 & 112.41 & 0.56 \\
C4X5 & 6031.16 & 203.98 & 113.33 & 0.55 \\
C4X6 & 6031.36 & 203.06 & 117.41 & 0.57 \\
C4X7 & 6273.43 & 204.60 & 113.89 & 0.55 \\
C4X8 & 5842.30 & 205.40 & 119.26 & 0.58 \\
C5X6 & 6369.76 & 206.85 & 120.37 & 0.58 \\
C5X7 & 6522.87 & 203.79 & 120.18 & 0.59 \\
C5X8 & 5781.21 & 195.18 & 110.28 & 0.56 \\
C6X7 & 5051.40 & 199.08 & 115.00 & 0.57 \\
C6X8 & 5822.13 & 199.44 & 114.44 & 0.57 \\
C7X8 & 5684.86 & 208.24 & 123.88 & 0.59 \\
General mean & 6001.43 & 200.40 & 113.24 & 0.56 \\
Contrast & 2100.65 & 22.78 & 25.66 & 0.07 \\
\hline GY: & & & & \\
\hline
\end{tabular}

GY: Grain yield $\left(\mathrm{kg} \mathrm{ha}^{-1}\right)$; PH: plant height $(\mathrm{cm})$ : EH: ear height $(\mathrm{cm})$; EP: ear position.

high favorable allele frequencies for GY evaluated in 12 environments.

However, this can only be predicted for hybrid production and evaluation because along with parent means, estimates can be affected (Guo et al., 2013). Per se, parent means are not reliable parameters to predict hybrids. There were, however, promising hybrid crosses even when parents exhibited low means in some characteristics, such as between VAR-05 $\times$ VAR-06. This is due to the complementarity of favorable loci among these varieties, which directly reflects heterotic crosses.

For parent prediction means through diallels, the methodology by Griffing (1956) requires hybrid combinations. A method that can predict the best possible hybrid combinations allows obtaining hybrids in breeding programs faster and more economically.

The BLUP, although not yet widely used for annual plants, has shown great potential for more relevant genetic progress (Bernardo, 1996; Lorenzana and Bernardo, 2009;
Jesus Freitas et al., 2014). Employing variance component estimates by REML and predicting breeding values by BLUP can be efficiently used (Resende and Sturion, 2001). The breeder could therefore predict progeny values by focusing only on the most promising combinations.

In the present study, correlations between estimated GCA and SCA and BLUP values were moderate to high (Table 3). This shows that you can use BLUP to select the best parents for the traits, especially for EH and EP which had the highest correlations. This was not observed for SCA which had low to moderate correlations, particularly for GY and EH. According to Cruz Baldissera et al. (2012), care should be taken in selecting and interpreting results when comparing combining ability estimates and BLUP.

When studying the parents for GCA, selection for progeny can be made for a specific performance trait. For example, parent VAR-01 has significant GCA values $(\mathrm{P}<0.05)$ and can be used in crosses to reduce $\mathrm{PH}, \mathrm{EH}$, and EP while parent VAR-06 can participate in crosses to increase EH, PH, and EP. The genotypes VAR-01, VAR-02, VAR-03, VAR-04, and VAR-06 showed high and positive GCA values for GY (Table 3), revealing the existence of favorable alleles for this character in these parents.

For intervarietal hybrids, the best combinations were $\mathrm{C} 2 \mathrm{X} 8$ and $\mathrm{C} 5 \mathrm{X} 7$ and both had high GY estimates. The C2X8 combination was selected to increase $\mathrm{PH}$ and the $\mathrm{C} 5 \mathrm{X} 7$ combination was selected to reduce it. These combinations revealed the crosses that complemented mean production the most and revealed the importance of complementarity and divergence between parents to exploit heterotic and genetic gains (Gowda et al., 2013a).

The predicted breeding value correlations with SCA for GY were moderate, generating opposite results in some combinations. while the SCA estimates showed a decrease in C1X2 combinations of $-230.19 \mathrm{~kg} \mathrm{ha}^{-1}$, BLUP estimated a productivity complement of $113.40 \mathrm{~kg} \mathrm{ha}^{-1}$ and the SCA estimates showed a decrease of $-230.19 \mathrm{~kg}$ $\mathrm{ha}^{-1}$; however, both parents showed positive GCA values, which was contradictory. This can be explained only by low complementarity between these parents. With BLUP estimators, both parents contribute to mean productivity, which is confirmed in the cross.

For both BLUP and combining ability, it was possible to identify $\mathrm{C} 2 \mathrm{X} 8$ as the best hybrid combination, originated from completely contrasting parents. When observing the $\mathrm{C} 2 \mathrm{X} 7$ combination, we found contrasting parents; involving the best parent in the cross (VAR-02) did not achieve significant productivity according to BLUP and GCA. This is probably because the methods were not sufficiently sensitive to separately identify contrasting parents for the characteristics under consideration. According to Bernardo (1995), BLUP can effectively predict when the degree of relationship between parents is known. Guo et al. (2013) corroborated this when they predicted hybrid corn from inbred lines and concluded that genetic architecture determines the accuracy of prediction. 
Table 3. Correlation between predicted breeding values (BLUPs) both general combining ability (GCA) for varieties and specific combining ability (SCA) for hybrids.

\begin{tabular}{|c|c|c|c|c|c|c|c|c|}
\hline \multirow[b]{2}{*}{ Parent } & \multicolumn{2}{|c|}{ GY } & \multicolumn{2}{|c|}{$\mathrm{PH}$} & \multicolumn{2}{|c|}{$\mathrm{EH}$} & \multicolumn{2}{|c|}{ EP } \\
\hline & GCA & BLUP & GCA & BLUP & GCA & BLUP & GCA & BLUP \\
\hline VAR-01 & 57.34 & 866.05 & $-6.52^{*}$ & -5.73 & $-7.16^{*}$ & -8.42 & $-0.017^{* *}$ & -0.010 \\
\hline VAR-02 & 227.29 & 695.19 & 0.45 & -7.11 & $-1.94^{*}$ & -5.65 & $-0.011^{* *}$ & 0.001 \\
\hline VAR-03 & 7.00 & 716.78 & -2.14 & -4.60 & -0.29 & -2.53 & 0.004 & 0.005 \\
\hline VAR-04 & 50.82 & 818.39 & 0.14 & -1.31 & -0.64 & -2.89 & -0.003 & -0.003 \\
\hline VAR-05 & -35.89 & 68.50 & 0.38 & -2.61 & 0.90 & -0.39 & 0.003 & 0.009 \\
\hline VAR-06 & 54.55 & 25.82 & 2.68 & 6.74 & $3.52^{* *}$ & 4.14 & $0.010^{* *}$ & 0.005 \\
\hline VAR-07 & -244.77 & -654.30 & 2.47 & 2.84 & $3.42^{* *}$ & 4.14 & 0.010 & 0.014 \\
\hline VAR-08 & -109.94 & -76.29 & 2.54 & 7.26 & $2.19^{*}$ & 4.14 & 0.003 & 0.005 \\
\hline Correlation & \multicolumn{2}{|c|}{$0.79^{* *}$} & \multicolumn{2}{|c|}{$0.71^{* *}$} & \multicolumn{2}{|c|}{$0.94^{* *}$} & \multicolumn{2}{|c|}{$0.86^{* *}$} \\
\hline Hybrid & SCA & BLUP & SCA & BLUP & SCA & BLUP & SCA & BLUP \\
\hline C1X2 & -230.19 & 113.40 & $-7.31^{*}$ & -3.87 & $-6.39^{* *}$ & -8.62 & -0.013 & -0.025 \\
\hline C1X3 & 104.77 & 197.40 & 1.77 & -2.05 & 1.70 & -3.33 & 0.003 & -0.005 \\
\hline C1X4 & -365.78 & -123.56 & -1.99 & -2.47 & -2.29 & -5.69 & -0.006 & -0.017 \\
\hline $\mathrm{C} 1 \mathrm{X} 5$ & -31.88 & 682.75 & 4.80 & -0.49 & 0.78 & -3.18 & -0.009 & -0.015 \\
\hline C1X6 & 456.09 & 484.25 & $-6.75^{*}$ & -3.09 & -2.02 & -3.28 & 0.010 & 0.001 \\
\hline $\mathrm{C} 1 \mathrm{X} 7$ & 270.68 & 135.65 & -0.81 & -1.48 & 2.61 & -0.81 & $0.015^{*}$ & 0.005 \\
\hline C1X8 & 225.65 & 198.69 & 0.05 & -1.22 & -2.73 & -4.39 & -0.014 & -0.017 \\
\hline $\mathrm{C} 2 \mathrm{X} 3$ & 195.15 & 384.62 & 0.44 & -0.47 & -0.37 & -1.62 & -0.003 & -0.005 \\
\hline $\mathrm{C} 2 \mathrm{X} 4$ & -68.95 & 212.13 & -0.18 & -0.01 & 0.35 & -1.42 & 0.002 & -0.008 \\
\hline $\mathrm{C} 2 \mathrm{X} 5$ & -306.41 & -69.31 & 0.79 & 0.33 & 2.32 & 0.49 & 0.008 & 0.001 \\
\hline C2X6 & 308.73 & 500.50 & 6.27 & 2.50 & 4.52 & 3.11 & 0.005 & 0.002 \\
\hline $\mathrm{C} 2 \times 7$ & -107.25 & -139.17 & -0.29 & 0.62 & $-5.29^{*}$ & -2.27 & $-0.025^{* *}$ & -0.016 \\
\hline $\mathrm{C} 2 \mathrm{X} 8$ & 1165.29 & 996.67 & 5.66 & 2.30 & 3.53 & 0.54 & 0.002 & -0.003 \\
\hline C3X4 & -8.82 & 984.82 & -5.08 & -2.11 & -1.76 & -1.67 & 0.006 & 0.004 \\
\hline C3X5 & -165.62 & -625.67 & -2.82 & -1.41 & -2.48 & -1.21 & -0.004 & 0.002 \\
\hline C3X6 & 660.78 & 596.79 & 3.95 & 1.13 & 2.58 & 2.96 & 0.002 & 0.009 \\
\hline $\mathrm{C} 3 \times 7$ & 252.76 & 880.98 & 1.47 & 0.38 & 1.58 & 2.36 & 0.004 & 0.011 \\
\hline $\mathrm{C} 3 \mathrm{X} 8$ & -542.59 & -388.47 & -2.94 & -0.84 & -3.21 & 0.27 & -0.008 & 0.0001 \\
\hline C4X5 & 162.09 & 190.56 & 2.49 & 0.72 & -0.64 & -0.41 & -0.009 & -0.006 \\
\hline C4X6 & 71.86 & 190.70 & -0.73 & 0.46 & 0.81 & 1.80 & 0.006 & 0.007 \\
\hline $\mathrm{C} 4 \mathrm{X} 7$ & 613.25 & 364.80 & 1.04 & 0.90 & -2.61 & -0.11 & -0.015 & -0.005 \\
\hline $\mathrm{C} 4 \mathrm{X} 8$ & 49.43 & 547.38 & 1.72 & 1.12 & 3.99 & 1.98 & 0.015 & 0.009 \\
\hline C5X6 & 477.41 & 434.07 & 2.83 & 1.52 & 2.23 & 3.41 & 0.002 & 0.009 \\
\hline C5X7 & 929.83 & 544.18 & -0.03 & 0.67 & 2.14 & 3.31 & 0.010 & 0.014 \\
\hline C5X8 & 55.49 & 108.08 & $-8.70^{* *}$ & -1.70 & $-6.54^{* *}$ & 4.99 & -0.007 & -0.001 \\
\hline C6X7 & -632.07 & -514.05 & $-7.04^{*}$ & -0.65 & -5.66 & 0.49 & -0.008 & 0.006 \\
\hline C6X8 & 5.98 & 402.38 & $-6.74^{*}$ & -0.55 & -4.99 & 4.97 & -0.005 & 0.005 \\
\hline C7X8 & 168.02 & -584.85 & 2.26 & 1.91 & 4.55 & 5.32 & 0.015 & 0.017 \\
\hline Correlation & \multicolumn{2}{|c|}{$0.63^{* *}$} & \multicolumn{2}{|c|}{$0.74^{* * *}$} & \multicolumn{2}{|c|}{$0.35^{*}$} & \multicolumn{2}{|c|}{$0.70^{* *}$} \\
\hline
\end{tabular}

* ${ }^{* *}$ Significant at the 0.05 and 0.01 probability levels, respectively.

GY: Grain yield $\left(\mathrm{kg} \mathrm{ha}^{-1}\right)$; PH: plant height $(\mathrm{cm})$; EH: ear height $(\mathrm{cm})$; EP: ear position; BLUP: best linear unbiased prediction.

\section{CONCLUSION}

There was a difference between diallel analysis and best linear unbiased prediction (BLUP) methods in terms of predicting efficiency. In addition, the ideal situation is that breeders use combining ability analysis together with breeding value (BLUP) estimates to identify promising genotypes more efficiently and promote the rapid development of new cultivars. Finally, if breeders choose to use only one methodology, BLUP was more efficient in determining parents related to higher earnings.

\section{ACKNOWLEDGEMENTS}

The authors thank the Foundation for Cordenação de Aperfeiçoamento de Pessoal de Nível Superior (CAPES) for granting a scholarship.

\section{REFERENCES}

Aguiar, C.G.D., C.A. Scapim, R.J.B. Pinto, A.T.D. Amaral Júnior, L. Silvério, e C.A.D.B. Andrade. 2004. Análise dialélica de linhagens de milho na safrinha. Ciência Rural 34:1731-1737. doi:org/10.1590/S0103-84782004000600010.

Bartlett, M.S. 1937. Properties of sufficiency and statistical tests. Proceedings of Royal Society of London A 160:268-282.

Bernardo, R. 1995. Genetic models for predicting maize single-cross performance in unbalanced yield trial data. Crop Science 35:141147. doi:10.2135/cropsci1995.0011183X003500010026x.

Bernardo, R. 1996. Best linear unbiased prediction of maize single-cross performance. Crop Science 36:50-56. doi:10.2135/ cropsci1996.0011183X003600010009x.

Cruz Baldissera, J.N., J.G. Bertoldo, G. Valentini, M.M.D. Coan, D.S. Rozeto, A.F. Guidolin, et al. 2012. Uso do melhor preditor linear não-viesado (BLUP) na predição de híbridos em feijão. Bioscience Journal 28:395-403. Available at http://www.seer. ufu.br/index.php/biosciencejournal/article/view/12330/9584 (accessed March 2015). 
Embrapa. 2006. Sistema brasileiro de classificação de solos. 2a ed. 306 p. Empresa Brasileira de Pesquisa Agropecuária (Embrapa), Embrapa Solos, Rio de Janeiro, Brasil.

Faria, V.R., J.M.S. Viana, F.M. Sobreira, e A. Costa. 2009. Seleção recorrente recíproca na obtenção de híbridos interpopulacionais de milho-pipoca. Pesquisa Agropecuária Brasileira 43:17491755. Available at http://seer.sct.embrapa.br/index.php/pab/ article/view/1030/5587 (accessed February 2015).

Fritsche-Neto, R., R.A. Vieira, C.A. Scapim, G.V. Miranda, and L.M. Rezende. 2012. Updating the ranking of the coefficients of variation from maize experiments. Acta Scientiarum Agronomy 34(1):99-101.

Gowda, K., M. Rajanna, and S. Ramesh. 2013a. Diallel analysis to estimate the gene action and combining ability of grain yield and its contributing traits in maize (Zea mays L.) Mysore Journal of Agricultural Sciences 47:758-764. Available at http://www. uasbangalore.edu.in/asp/periodicals .asp (accessed July 2015).

Gowda, M., Y. Zhao, H.P. Maurer, E.A. Weissmann, T. Würschum, and J.C. Reif. 2013b. Best linear unbiased prediction of triticale hybrid performance. Euphytica 191:223-230. doi:10.1007/ s10681-012-0784-z.

Griffing, B. 1956. Concept of general and specific combining ability in relation to diallel crossing systems. Australian Journal of Biological Sciences 9:463-493. Available at http:// www.publish.csiro.au/?act=view_file\&file_id=BI9560463.pdf (accessed February 2015).

Guo, T., H. Li, J. Yan, J. Tang, J. Li, Z. Zhang, et al. 2013. Performance prediction of $\mathrm{F} 1$ hybrids between recombinant inbred lines derived from two elite maize inbred lines. Theoretical and Applied Genetics 126:189-201. doi:10.1007/s00122-0121973-9.

Hallauer, A.R., M.J. Carena, and J.D. Miranda Filho. 2010. Quantitative genetics in maize breeding. Springer, New York, USA.

Henderson, C.R. 1975. Best linear unbiased estimation and prediction under a selection model. Biometrics 31:423-447. doi:10.2307/2529430.

Jesus Freitas, I.L., A.T. Amaral Junior, A.P. Viana, G.F. Pena, P. Silva Cabral, C. Vittorazzi, et al. 2014. Ganho genético avaliado com índices de seleção e com REML/Blup em milho-pipoca. Pesquisa Agropecuária Brasileira 48:1464-1471. doi:10.1590/ s0100-204x2013001100007.

Júnior, F., A.T. Amaral Júnior, M.G. Pereira, C.D. Cruz, e C.A. Scapim. 2006. Capacidade combinatória de milho pipoca por meio de dialelo circulante. Pesquisa Agropecuária Brasileira 41:1599-1607. Available at http://www.scielo.br/pdf/pab/ v41n11/a05v4111.pdf (accessed July 2015).

Lorenzana, R.E., and R. Bernardo. 2009. Accuracy of genotypic value predictions for marker-based selection in biparental plant populations. Theoretical and Applied Genetics 120:151-161. doi:10.1007/s00122-009-1166-3.
Machado, A. 2014. Construção histórica do melhoramento genético de plantas: do convencional ao participativo. Revista Brasileira de Agroecologia 9:35-50. Available at http://www.abaagroecologia.org.br/revistas/index.php/rbagroecologia/article/ view/15278/9973 (accessed September 2015).

Machado, J.C., J.C.D. Souza, M.A.P. Ramalho, and J.L. Lima. 2009. Stability of combining ability effects in maize hybrids. Scientia Agricola 66:494-498. doi:org/10.1590/S010390162009000400010.

Oliboni, R., M.V. Faria, M. Neumann, J.T.V. Resende, G.M. Battistelli, R.G. Tegoni, et al. 2013. Análise dialélica na avaliação do potencial de híbridos de milho para a geração de populaçõesbase para obtenção de linhagens. Semina Ciências Agrárias 34:718. doi:org/10.5433/1679-0359.2013v34n1p7.

Rangel, R.M., A.T. Amaral Júnior, A.P. Viana, and S. Paiva Freitas Junior. 2007. Prediction of popcorn hybrid and composite means. Crop Breeding and Applied Technology 7:287-295. Available at http://www.researchgate.net/publication/26638334_Prediction_ of_popcorn_hybrid_and_composite_means (accessed January 2015).

Resende, M.D.V.D., e J.A. Sturion. 2001. Análise genética de dados com dependência espacial e temporal no melhoramento de plantas perenes via modelos geoestatísticos e de séries temporais empregando REML/BLUP ao nível individual. 81 p. Embrapa Florestas, Colombo, Paraná, Brasil.

Ribeiro, C.B., M.A.P. Ramalho, e P.E.R. Prado. 2014. Contribuição dos caracteres vegetativos e reprodutivos da planta de milho para a heterose na produção de grãos. Revista Brasileira de Milho e Sorgo 13:59-68. Available at http://rbms.cnpms.embrapa.br/ index.php/ojs/article/view/429/pdf_73 (accessed January 2015).

Rocha, F.D., J.C. Stinghen, M.S. Gemeli, J.L.M. Coimbra, and A.F. Guidolin. 2014. Diallel analysis as a tool when selecting parents for beans. Revista Ciência Agronômica 45:74-81. doi:org/10.1590/S1806-66902014000100010.

Silva, K.J., C.B. Menezes, F.D. Tardin, V.F. Souza, e C.V. Santos. 2014. Comparação de métodos de correção de estande para estimar a produtividade de sorgo granífero. Pesquisa Agropecuária Tropical 2:175-181. doi:10.1590/S1983-40632014000200005.

Vencovsky, R. 1972. Princípios de genética quantitativa. 97 p. Escola Superior de Agricultura "Luiz de Queiroz", Universidade de São Paulo, Piracicaba, São Paulo, Brasil.

Vivek, B.S., O. Odongo, J. Njuguna, J. Imanywoha, G. Bigirwa, and K. Pixley. 2010. Diallel analysis of grain yield and resistance to seven diseases of 12 African maize (Zea mays L.) inbred lines. Euphytica 172:329-340. doi:10.1007/s10681-009-9993-5.

Werle, A.J.K., F.R.A. Ferreira, R.J.B. Pinto, C.A. Mangolin, C.A. Scapim, and L.S.A. Gonçalves. 2014. Diallel analysis of maize inbred lines for grain yield, oil and protein content. Crop Breeding and Applied Biotechnology 14:23-28. doi:org/10.1590/ S1984-70332014000100004.

Zhang, Y., M.S. Kang, and K.R. Lamkey. 2005. DIALLEL-SAS05. Agronomy Journal 97:1097-1106. doi:10.2134/agronj2004.0260. 